\title{
BILINGUALISM AND FAMILY: PARENTAL BELIEFS; CHILD AGENCY
}

\begin{abstract}
Summary. Globalizing forces and choices move families out of their native language (L1) environments to places where their heritage language (L1) is in the minority. This study focuses on academic sojourner families and their school-aged children and asks how they maintain their native language, during limited stays in the USA (1-7 years). How can native language be maintained relative to the social, emotional, linguistic, and personal challenges faced by parents and children during their sojourn in the USA? Is the task of sustaining a child's native language in the newly-entered social and scholastic context of a dominant language undermined by underestimation of the impact of erosionary forces on the heritage language? These are some of the key issues identified in a larger on-going study, of which a sub-sample of three linguistically well-informed families (parent-child pairs) is presented here. Findings include the significant impact of parental beliefs regarding the resilience of language on the maintenance of the L1 coupled with the emerging sociolinguistic competence and agency of the child in the L2 environment, which in turn can raise separate challenges for the parent, as well as the child, and for the parent-child relationship.
\end{abstract}

Keywords: family language maintenance, heritage language, language strategies, minority language, native language maintenance, bilingual language erosion.

\section{Family as potential hub of language proliferation}

Given the strong pressure many families and students feel to acquire a broadlyused language such as English, or to give precedence to a dominant or majority language, this article argues that one of the key sites for the promotion of bilingualism is the family. But whether that power is realized depends to a large extent on parental beliefs and stances regarding the nature and resilience of language and the quality of the parent-child relationship. These beliefs and familial relationships ultimately guide them in the provision of an environment and conditions that nurture language growth or permit language to erode and ultimately be extinguished. 
While many other factors can influence the development, loss, or erosion of a minority or heritage language, the only environment over which a parent has a fair amount of control is the home. Here, the most intimate links are possible between familial ties binding language with emotion, affection and rich experience; often with an extended family that includes grandparents, cousins and other relatives set against the rich cultural backdrop of family events.

Fishman (2000) asserts that the key to intergenerational language maintenance is interaction in smaller social circles (such as the family unit) and the use of the ethnic language at home by women with their children. Others, such as Garcia (2003) agree, "It is clear that the family unit and the home domain will remain important in language maintenance efforts and research" (p. 24). The familial environment constitutes a site which has been studied far too little when its potential for nurturing language growth is so great.

The present study demonstrates that although resolute strategies and planning on the part of parents is of key importance in first (L1) language maintenance, it must be coupled with the resolve, and moreover, with the agency of the child. Also of great significance in the data is the degree of parental investment in the relationship they have built with their children, as well as the ease, frequency and quality of communication they have established and nurtured over the years.

Most research on heritage language maintenance has focused on immigrant families and students in classrooms, whereas the focus of the present study is on sojourning academics in the USA and their school-aged children who are learning English. These families find themselves largely in isolation from any local language community. Thus, the onus falls entirely on the family unit to maintain their native language.

How, then, might highly educated language specialist parents and their children assert their agency to perform their socio-cultural roles as bilinguals who continue to sustain their native language as they acquire an additional language? How do parental beliefs and child agency impact the successful maintenance (or erosive loss) of the L1 while acquiring the L2 in this new socio- 
cultural-scholastic context of the dominant language? These were some of the questions posed by this study.

\section{Decisions and Investments}

Increasingly, parents are bringing their children to English-dominant countries believing that language learning for their children will be best achieved in an immersion environment, but also to invest in their children's future global competence. Investment into learning a new language in a new cultural context, however, has its costs and affordances (King, Fogle, \& Logan-Terry, 2008; Kouritzin, 2000; Norton Peirce, 1995). Many longer-term visitors (sojourners) who bring their children with the overriding goal of English language acquisition (L2) may not be aware that successful native language maintenance is, to a great extent, the result of emerging parental agency (i.e., ability to decide and take action) in fostering their native language. The challenge is to do so while supporting their children to develop their own agency in fitting into the linguistic, social, and academic context of their new reality.

The parents in this study had left academic jobs or advanced studies to bring their young families to the USA. Often, a spouse took a leave of absence or quit a job in order to bring one or more of their own children to the USA to learn English. Because these language educators were aware of the linguistic flexibility of young children to acquire a second native language, they felt the sacrifices were worth it.

\section{Studies on Family Language Maintenance}

Several key studies have been conducted that focus on families with young, adolescent bilinguals (Guardado, 2002; McKay \& Wong, 1996; Schechter \& Bayley, 1997). These studies aim to bring insight into how families attempt to sustain the native language in their homes. Most of these studies were conducted in North America and Australia among immigrant families interested in maintaining their native language (L1) in the face of English as the dominant 
national language as the children grow cognitively and attend school. These studies explore the degree of investment that parents and children place into learning or maintaining their native language or another language.

In the present study, the need for simultaneous dual investment by parents into both the L1 and L2 was underscored by the fact that each of the focal children arrived in the USA before the age of 9. In second language acquisition, cognitive development and L1 proficiency are linked to age. Collier (1989) points out that L1 (native) acquisition with simultaneous cognitive growth is a complex process that takes at least 12 years. Her findings are that children between the ages of 6-12 are particularly challenged to develop increasingly complex language skills in their native language in terms of morphology, syntax and semantic development, along with literacy skills. The expanding cognitive demands of school place further challenges on children when these factors simultaneously come into play in a new, additional language. Put simply, the children's cognitive and linguistic domains are still evolving. It stands to reason that the younger the child and the less extensive their vocabulary and linguistic base is in the $L 1$, the more fragile the $L 1$ is. The expansion of the child's cognitive capabilities requires a continuous and commensurate expansion in their vocabulary and complex linguistic structures used to encode increasingly complex and abstract thoughts. Because children's cognitive development and concomitant growth in new vocabulary typically occurs most intensively in school, the language of the school quickly dominates (Collier, 1989; Döpke, 1992; Schecter \& Bayley, 1997; Schwartz, 2013; Wong Fillmore, 1991). In this dynamic evolutionary linguistic flux, the norm is for the native language to be rapidly supplanted by the dominant language.

Schecter and Bayley (1997) interviewed four families, two families in Texas and another two in California, regarding their language maintenance strategies for raising their children (focal child usually about 12 years old) bilingually. In each case, the parents found that their child had slipped incrementally away from the family language, although the cultural and emotional bonds were still strong, albeit held primarily by cultural customs. Entry into school where English dominated, peer influence, and less strict 
parental attitude toward speaking the language at home contributed to the decline, although several of the families developed compelling strategies to try to rekindle the home language.

Another study by McKay and Wong (1996) investigated Chinese adolescent immigrants in junior high school and the coping strategies they used to invest efforts into learning English while simultaneously using their native Chinese to gain power and agency, thereby exerting their bilingual identities in complex, context-driven ways. Although these studies focused on immigrant students, rather than visitors or sojourners, the issues they explored also inform the present study. It is striking that in each of these studies, the decision to maintain the language is ultimately made by the child, but the bonding, the agency with which the child formulates strategies, and the investment are derived from the foundation laid by parental investment in the child.

Several studies point out that maintenance of the $L 1$ is a critical link to one's ethnic heritage and is key in forming a picture of one's own identity which then reinforces the desire to maintain the L1. Tajfel $(1974,1981)$ pointed out that our identities are derived as much from our perceptions of ourselves as the perceptions of others. How one gains a sense of one's own identity is socially constructed through language use. Gumperz and Cook-Gumperz (1982) further underscore the central role of language, maintaining that both ethnic and social identity is in large part established through language use. Indeed, when more than one language is spoken, one can extrapolate that multilingualism greatly impacts one's identity or sense of self and how one operates in multiple social worlds (Baker, 2011).

\section{Native Language Maintenance: Expectations}

This study is a subset of a larger ongoing study of international parents who are pursuing their own educations or careers in the area of language studies and have brought their children to the USA for 3-7 years. The overall study focuses on the choices parents have made and their beliefs regarding $L 2$ acquisition and native language resilience which informed those choices. Their children have 
also been asked to contribute their voices and views to offer deeper insight into their ongoing language and social identity development while enrolled in local English-medium schools.

The researcher posits that these parents would be proactive in making concrete plans and rules for home language practices, ensuring the maintenance of the native $\mathrm{L} 1$, while also aiding the acquisition of the second. Especially given the lack of a supportive speech community, parents would be cognizant of the need to buttress and protect the native/heritage L1 and devise some agreements with their children regarding L1 use in the home. In establishing bilingualism as their goal, they would also help their children develop their agency and identity in the challenging new linguistic, scholastic, social and psychological reality they had entered.

\section{Research Questions}

The overarching question investigated in this study is whether being wellinformed in the field of language education/acquisition would give parents greater agency in guiding their children toward the maintenance and further development of their heritage/native language (L1) while surrounded by the majority second language (L2) that their children are seeking to acquire. The investigation sought further insight into the following questions: What specific beliefs regarding the nature and resilience of language inform home language use? Do parents perceive a need to establish conditions and rules for their children's use of the native L1 in the home?

\section{Participants}

The participants were three school-aged children who had come to the United States before the age of ten and would stay for several years. The focal parents were language professionals who were pursuing a degree or teaching in the language education area of higher education. Table 1 offers the participants' backgrounds and information on the child at the time of the interviews. 


\section{Participants}

\begin{tabular}{|c|c|c|}
\hline $\begin{array}{l}\text { Focal } \\
\text { Child }\end{array}$ & * Interviewed Parent & Focal Child's Background \\
\hline $\begin{array}{c}\text { \#1 } \\
\text { Maria }\end{array}$ & $\begin{array}{l}\text { *Mother - (age: mid 30s) doctoral } \\
\text { student in language education } \\
\text { Father - visiting professor }\end{array}$ & $\begin{array}{l}\text { Arrival in USA at age 5; interviewed at } \\
\text { ages } 12 \text { and } 13 ; \text { L1 Slovak } \\
\text { Fluent in English: Honors student } \\
\text { Home-schooled in Slovak } \\
\text { Will return to native country in about } \\
\text { two years }\end{array}$ \\
\hline $\begin{array}{c}\text { \#2 } \\
\text { Erhan }\end{array}$ & $\begin{array}{l}\text { *Father - (late 20s) Master's student } \\
\text { in Language Teaching } \\
\text { Mother - Turkish teacher }\end{array}$ & $\begin{array}{l}\text { Arrival in USA at age 3; eight years old } \\
\text { at time of study } \\
\text { Fluent in English } \\
\text { Understands but does not speak } \\
\text { Turkish } \\
\text { Will return to native country in about } \\
\text { one year }\end{array}$ \\
\hline $\begin{array}{c}\text { \#3 } \\
\text { Andrea }\end{array}$ & $\begin{array}{l}\text { *Mother - (mid 40s) language } \\
\text { educator } \\
\text { Father - literature instructor }\end{array}$ & $\begin{array}{l}\text { Arrival in USA at age } 9 \text {; interviewed at } \\
\text { ages } 10 \text { and } 11 \\
\text { After } 1.5 \text { years, refuses to speak } \\
\text { Hungarian } \\
\text { Will return to native country in about } \\
\text { two years }\end{array}$ \\
\hline
\end{tabular}

\section{Method}

Operating on the assumption that maintenance of culture and language are bound together and that these play out in children's shifting, diverse identities as they move among social contexts, the present study was undertaken in a Midwestern university town and focuses on the parental role and children's fluctuating agency and investment into the endeavor to maintain their native language while learning English. Each child will eventually return to their home country after a stay of several years. Three participant parent-child pairs (Slovak mother-child; Turkish father-child; Hungarian mother-child) were chosen to represent the spectrum of child outcomes and to illustrate beliefs and practices emblematic of parents and children interviewed for the larger study on L1 maintenance. 
Parents were sent an initial background information sheet via email in which they supplied demographic information about themselves and the focal child. Questions included date of arrival, children's ages (years and months at arrival), present home language policy and actual use (native language or English), and the goal of the family's stay in the USA. The protocol is discussed below. Focal parents were interviewed twice, at the beginning and end of one academic year. The two parent interviews lasted 60-80 minutes each. The focal children were interviewed twice, once in the fall at the start of the school year (late August) and again in spring at the end of the school year (early May). Each child interview was 30 to 40 minutes in length, conducted in English with the parent present.

\section{Interviews}

The interviews were conducted in a casual environment or at the interviewee's home. Questions focused primarily on language and cultural maintenance and challenges and issues encountered since coming to the United States. Informal conversation commenced around the topics in the open-ended interview questions sent to parents in advance. Both the parent and focal child were asked about their evolving attitudes and practices toward maintaining their native language in the home, with friends, and at school.

The study approach was to invite each parent and child to tell the story of their language journey and "fitting in" since arrival in the United States. This narrative approach helped move the interviews along, as parents spoke of their goals and intentions, and of enrollment of their children into local schools, their linguistic and scholastic progress and enculturation. Notes and transcripts from the audio recordings of their narratives during the open-ended interviews formed the data from which themes and issues emerged that were further analyzed for instances and illustrations of agency asserted through (1) strategies for acquisition of English (the L2), (2) strategies for maintenance of (the L1) native language (3) beliefs and evolving perspectives on language erosion and loss, and (4) issues related to identity and belonging. Thematic analysis was 
used to identify emerging and recurrent themes (Aronson, 1994) in the transcripts across the conversations with the children and the parents, focusing on how they qualitatively construct their stances and descriptions of their enactments of native language use in the home and in outside contexts.

\section{Results and Discussion}

Working initially from the narrative structure of episodes or stages on a journey, interviews yielded some key themes, first in the parental category and then in the child category. These included parents' initial goals and intentions regarding the maintenance of the L1 and acquisition of the L2, and their views of their child's language resiliency, as well as the belief that heritage language loss, while somewhat problematic, is repairable with return and re-immersion in the familial and social environment of the native language. Parental concerns were centered on the acquisition of the $\mathrm{L} 2$ and the emotional well-being and agency of their children in the $L 2$ environment. Children's concerns were socially oriented and introspective about their own language erosion and their increasing agency in the American culture and English language.

\section{Initial Parental Goals and Intentions}

In all three cases, this subgroup of parents expressed their wish to put key emphasis on rapid English acquisition for their children, with the ultimate goal of superior bilingual capabilities coupled with socio-cultural agency in both English and their native language. When asked whether there were policies, strategies or agreements, either explicit or implicit for home language use, only the Slovak mother-child pair confirmed an explicit understanding regarding the use of the native language with siblings and parents. Before leaving Slovakia, Maria's mother had gathered appropriate textbooks for her children so they could read and do schoolwork using the L1. She didn't want her children to fall too far behind the Slovak curriculum of their peer group at home. Initially, her concern 
was oriented toward scholastic progress, rather than an explicit desire to nurture the heritage language - but she actually achieved both ends. The language spoken at home was chiefly Slovak; however, Maria began code-switching after entering school. Maria's mother insisted that the children speak Slovak within the family. She felt it unnatural to speak any language other than her mother tongue with her children, and though there were no formal agreements, there was an understanding that they were only visiting the USA and Slovakia was their home.

Andrea and her mother (the Hungarian mother-child pair) and Erhan and his father (the Turkish father-child pair) were far more indicative of the responses in the larger study with respect to a family language policy. Most parents with school-aged children (such as the case of Andrea) were concerned with the slow start and struggles with English acquisition, particularly as the academic and cognitive demands of schooling increased, so that the native L1 was not a focal point of any concern. Andrea's mother was initially quite worried about her lack of fluency or halting speech in English. Parents tended to put their linguistic resources into scaffolding and fostering English acquisition, using a wide array of strategies. Their desire was for their children to (a) fit into the school environment, (b) understand instruction, (c) excel in academics and (d) achieve social enculturation. Even Maria's mother expressed concern:

You know, I worry that Maria is not understanding what the teacher wants. This will affect her grades. [Maria's mother, interview 1]

...at school, there are very nice children, but she finds it hard to talk to them. What can I do to get her friends? [Andrea's mother, interview 1]

One of the major concerns of many parents relates to the emotional and psychological well-being of their children. Both parents and children reported concern with the upheaval that leaving familiar schools and friends had caused. The need to keep in touch with friends while also trying to fit in and gain agency in the new socio-cultural world translated into a great deal of parental concern 
that their children gain the ability to act decisively on their own behalf; that is, to have greater agency in all the choices that were offered in school and social situations. "Fitting in" and being comfortable were two recurring themes in both the parental and child interviews.

But parents with younger children such Erhan's (who had come at the age of 3) generally took a more relaxed stance toward the acquisition of the L2, relying upon the intrinsic elasticity of childhood linguistic abilities and the environment (American playmates, daycare, kindergarten). Erhan's parents noted his progress in the $L 2$ and the language shift that occurred:

Before he started daycare, Erhan used to prefer Turkish over English, because he did not know English at that point. But he picked up English, and then over time, he switched from Turkish to English. [Erhan's father, interview 1]

Erhan's parents felt this was a natural progression and higL1y valued their son's language preference. Erhan's parents spoke both English and Turkish with one another but interacted exclusively in English with Erhan, because that was the language in which he addressed them. His language preference was highly valued by his parents.

\section{Parental Belief in the Resilience of Language}

Most parents in the larger study admitted that the overriding concern about linguistic achievement (learning English) and social needs led them to allow increasing use of English in the household. Many were caught off-guard and noticed L1 erosion only after their own children were already feeling its effects.

At first, my husband and I didn't think about her native language. I was focusing on her English, because I wanted her to adjust quickly to the surroundings and to school. One year later, I thought about her 
Hungarian, because her Hungarian was getting choppy and halting. She forgets lots of Hungarian words. [Andrea's mother, interview 2]

When asked what Erhan did when he was unable to express a thought in his native language, his father replied, "Then he just doesn't say it." He went on to say:

They have their grandmother now [visiting for several months]. She does not know English. With her they always need to communicate in Turkish all the time. So they try to say things here and there, and when they can't say [what they want], they come to me or their mom and [ask] 'how do you say that in Turkish?' So we tell them the word and the sentence, and they go to her and say the sentence or the word. This is what happens. [Erhan's father, interview 2]

He did not express concern that Erhan and his siblings now "always prefer to speak in English." Although he rated Erhan's active oral speaking ability in Turkish as "low and minimal," his father was the most outspoken regarding his strong belief in the resilience of the native language:

We do not believe that they, I mean Erhan and his siblings, are forgetting completely the mother tongue. We are not about this. We take it easy. So when we go back to Turkey, we believe that they can pick it up real quick and they will not have any problems. So we consider kids to be bilingual at this moment. Although most of the time they prefer English to communicate with. [Erhan's father, interview 2]

The view that the erosion or loss of productive expression in the L1 is not a problem of great magnitude because it is happening during pre-adolescence and can be recovered was one that was shared by a surprising number of parents in the larger study. Andrea's mother noted the erosion of the mother tongue after more than a year of allowing her daughter to code-switch in order to keep an 
open line of communication with her and to ease expressive difficulties. After a year and a half, Andrea felt more comfortable using English and refused to speak Hungarian.

As long as she still understands Hungarian, it's fine. [Andrea's mother, Interview 2]

Maria's mother concurred, saying that she's not overly concerned about erosion of the L1:

We don't worry about it. We will go back in a few years. She will make friends and it will be OK. [Maria's mother, interview 1]

When discussing home practices in relation to speaking the $\mathrm{L} 1$ at home, parents spoke of their child's struggle, frustration, resistance, and the impossibility of translation of events, terms, experiences and concepts brought home from American social encounters and interactions at school into the L1. As children gained greater agency in the L2 environment and felt more and more at ease navigating different linguistic registers and social situations, parents reported a concomitant drop in their willingness and comfort in expressing themselves adequately in the native language. Yet this change happened so incrementally that erosion and resistance to speaking the $\mathrm{L} 1$ had made a significant inroad by the time parents noted it.

You know ... I am afraid I am losing my daughter... (long pause). I look at her struggling to speak in our language and I can't let her be in pain. I don't want this issue of language to push her away from me. [said privately after daughter left the apartment] [Andrea's mother, interview 2] 


\section{Parental Assessment of Child's L1 and L2 Facility}

Table 2 presents a brief overview of the focal children from each parent's assessment. Parents' perceptions of their child's language facility, reasons for (not) speaking the native language, and social/emotional reasons were given to explain language loss or maintenance. The data demonstrated tensions and losses in both parties' perceptions.

Table 2

\section{Children through Parental Perception}

\begin{tabular}{|c|c|}
\hline Parent & View of Focal Child \\
\hline $\begin{array}{l}\text { \#1 Maria's } \\
\text { mother: } \\
\text { Ph.D. } \\
\text { student }\end{array}$ & $\begin{array}{l}\text { Mother characterizes Maria's L1 use as cooperative. Maria started } \\
\text { speaking more English at home with her younger siblings after she } \\
\text { entered American school. Responded well to encouragement to speak } \\
\text { Slovak at home and to keep up with simultaneous Slovak home- } \\
\text { schooling. Mother noticed some degree of difficulty in expressing more } \\
\text { complex thoughts in Slovak after two years in the USA. }\end{array}$ \\
\hline $\begin{array}{l}\text { \#2 Erhan's } \\
\text { father: } \\
\text { Ph.D. } \\
\text { student }\end{array}$ & $\begin{array}{l}\text { Father characterizes Erhan's L1 use as unpressured. He describes him } \\
\text { as a well-adjusted child who understands Turkish, but speaks almost } \\
\text { exclusively in English. Father believes the erosion of language is as } \\
\text { natural as is its acquisition. Feels certain that Erhan will never forget his } \\
\text { native language; he will readily reacquire productive Turkish with a } \\
\text { return to their home country in a few years. }\end{array}$ \\
\hline $\begin{array}{l}\# 3 \\
\text { Andrea's } \\
\text { mother: } \\
\text { visiting } \\
\text { scholar }\end{array}$ & $\begin{array}{l}\text { Mother characterizes Andrea's L1 use as resistant. Andrea's L2 socio- } \\
\text { linguistic adjustment was fraught with difficulty in the first year. But her } \\
\text { L2 linguistic and social agency (enculturation) grew exponentially } \\
\text { thereafter. She started code-switching early on and resisted speaking } \\
\text { her native language. Mother says Andrea understands everything, but } \\
\text { now usually replies in English. Understands her native language, but } \\
\text { feels more comfortable speaking English. Mother does not want to } \\
\text { stress her. }\end{array}$ \\
\hline
\end{tabular}

Even with the advantage of linguistic knowledge regarding language acquisition and erosion and loss, most remarkable in the findings for two out of three participant families, was the lack of specific plans or actionable strategies for ensuring both the survival and the further age-appropriate development of the L1 by parents who have access to linguistic funds of knowledge and language capabilities. (This approximate ratio holds for the larger study, as well). In fact, parents and their children seem to focus so tightly on the stated goal of bilingualism via English that it is at the expense of the language maintenance 
goal; i.e., the co-evolution of the $L 1$ in tandem with the developing $L 2$. Respondents (both parents and children) were unanimous in the larger study in stating that they absolutely intended to keep the native language (L1). By perceiving their child's L1 acquisition in a sense as an achieved goal, they apparently fail to nurture its productive use, noting L1 erosion only after it has reached a significant stage of loss.

\section{Children's Views}

In response to the question of the ways children conceptualize their progress in English and any loss or erosion of their native language while staying in the USA, the findings below represent the children's views in their own voices, but occasionally are represented in the voice of a parent.

Finding 1: Limited social interactions in the L1. The two focal girls' interviews revealed the scope of social interaction in their native language to be very limited. Andrea stated that she found using their native language "kind of boring," because her interactions were primarily with family members; but more importantly to her, she had few Hungarian age mates or friends with whom to socialize. With her mother's encouragement, she would occasionally socialize with younger Hungarian children on the rare occasions when there were social functions, but language use quickly turned to English. After one year, Andrea spoke increasingly in English - or chose to remain silent. Erhan was essentially in the same social situation as Andrea, but he had chosen to limit his productive speech to English, leading his few Turkish playmates to do the same - with the approval of his parents. Maria was restricted to speaking Slovak exclusively within the family, including with a grandmother who came for six months, but she viewed this restriction as quite natural for the family.

Finding 2: Child's awareness of language loss. It was striking to note a pattern among the children who saw their own language erosion earlier than their parents had noticed it. Several times, during interviews, the child would reveal an occasion where the parent would remark that a specific event 
had occurred earlier than when the parent had noted language erosion to have started.

Andrea: I could think it [something she wanted to say], but it didn't come out like my thought [Remarking on her early awareness of erosion during a game she was playing at an event].

Andrea's mother: Oh, darling, but you were speaking fine then.

Andrea: No, Mom, I really couldn't! [Andrea, interview 1]

Maria also noted her awareness of her native language eroding:

It kinda started with playing at home with my brother and sisters...you know, stuff [language] you learn at school, like loose leaf paper or binder. I just couldn't say what to do ... like 'directions' in Slovak. [Maria, interview 2]

Finding 3: Child's agency in language choices. In the data that emerged on language choices that the children made, the child's emerging agency manifests itself in language behaviors that aid or erode the L1. Maria expresses her determination to take back control of her own native language:

Maria: We went back to Slovakia and our cousins teased us about our American accents, so we agreed that we [her younger brother] will speak only Slovak when we go back to America. [Maria, interview 1, after first visit to Slovakia after 7 years in the USA]

On the other hand, Andrea decided by the following fall not to speak her native language any more. She spoke of a school project for which she had to choose a country about which to report. She had chosen Iceland - stating that it was remote and she liked being cold and not having to speak to anyone: 
Researcher: Andrea, so what's up, why don't you want to speak Hungarian anymore?

Andrea: ummuh (shrugging, unwilling to speak for the duration of the interview) [Andrea, interview 2]

In her refusal to speak her native language, she chose to assert her agency and withdraw from investing further in her native language (Norton Peirce, 1995).

A more socially oriented focus was demonstrated in Maria's assertion of agency in orchestrating friends to help with her native language, "...since we are going to Slovakia during the summer, my friends will help." Erhan had asserted his agency early on, choosing to speak exclusively in English and actually causing language shift in the usage of his parents as well. Rather than the parents exercising L1 agency, in each of the three cases profiled here, it is the child's agency that is foregrounded. In Andrea's and Erhan's cases, it is their agency which determines the status and actual home use of the native language. Or more precisely, it is their resistance and easy-going neglect of the heritage language that brings about erosion of their productive ability, leaving both with linguistic gaps in their native language.

Finding 4: Ethnic identity. Despite their advanced English ability and cultural assimilation, all three children indicated a strong social and psychological attachment to their ethnic identity. This is shown through their choice of friends and continued self-identification as members of their native cultures. For example, when asked if they are more American after being in the United States for more than one year, most children firmly stated that they were not. Yet, in almost all cases, the child would quickly turn to the parent to verify their assertion. These moments were reflective of the bond of trust and affirmation they tended to display during the interviews. Even Andrea, who was refusing to speak by the second interview, when prompted to speak at least one word in response to the ethnicity question, was willing to nod her head. Maria, 
on the other hand, had no hesitation, explaining how inconceivable it would be to discontinue speaking her native language:

Researcher: If you would be planning to live in the USA permanently, how important would it be to keep speaking Slovak?

Maria: We have to keep learning Slovak because we live in the States!

Researcher: Why? You can communicate in English in the States.

Maria: If an American would go to Slovakia, but stop talking English because he will live in Slovakia... Don't you think that it is weird? Like it would be weird for me to talk English with my mom or dad, you know?

Maria: We aren't Americans even though we live here. [Maria, interview 2]

With this assertion, Maria's sense of agency and sense of ethnic identity is underscored through her determination to continue to speak and develop her native language. The investment by children and parents in learning a language is thought by Norton Peirce (1995) to lead to changes in social identity, which in turn lead to further investment. Of the three cases presented here, Maria is the most invested and certainly has been the most successful in preserving her L1. But this is not to say that a strong ethnic identity is strictly tied to linguistic ability. In Erhan's case, his father related his efforts to explain their Muslim and Turkish heritage and customs:

We are from Turkey, a different culture, and we have a different religion. Erhan is aware of this. We constantly speak about Turkey in our family. We usually say 'this is how Americans would do and Christians would do. This is how we do things and celebrate.' Erhan is proud to be Turkish. [Erhan's father: interview 1]

Parents' perception of the child's emotional well-being and "comfort" is a key factor that trumps the adherence to a firm stance on insisting the child speak or use the native language. Two out of three parents in this study went to the default position of being content with merely the child's L1 comprehension. 
At first she expressed herself in Hungarian. After a little bit, she gets kind of angry about herself. If she cannot express herself, I guess part of it is my fault. I cannot understand her. So I ask her again and again, restate her sentence. It takes a very long time. She wants to express, but... [Andrea's mother, interview 2]

\section{Summary and Discussion}

Given that each of the participant families would be living in the USA for several years, the expectation of this investigation was that the deeper linguistic knowledge of parents, coupled with their own bilingual capabilities, would lead them to take precautions to ensure the robust survival of the native language. With these advantages, the prediction was that parents would be proactive in ensuring the maintenance of the native L1 even while aiding the acquisition of the second (or the L2). They would have plans in place that would include their children in decision-making concerning the use of language in the home. While this was partially true in one of the cases profiled, in all three cases, the agency of the children soon became the ultimate steering mechanism for actual practice within the household. In the face of social, emotional, linguistic, and scholastic challenges, children and parents reached certain junctures that caused a shift in attitudes and home language practices. De Houwer (1999) points out that in childhood bilingualism, parental beliefs and attitudes impact child language use, but the child's language behavior and attitudes also influence parental stances and language decisions, as evidenced in the data.

All three families in the current research were aware of the importance of heritage language maintenance, but only one of the three parent-child pairs reported more than a general family agreement or specific actionable plan. The other two families had no rules, holding a great belief in the resilience of language and the relative ease of regaining lost productive power. The Slovak mother was alone in insisting upon daily use of the heritage language, whereas the other two families saw preadolescent language as resilient and firmly 
believed that their children would be able to reclaim productive use of the $L 1$ with re-immersion in the native language environment. However, even the children who chose not to speak the L1 productively still identified strongly with their ethnic ties. This was underscored by 12 -year old Maria, who with great conviction and simple logic reasoned:

We have to learn Slovak because we are Slovakians. [Maria, interview 2]

Though aware of the pressure of an L2 as an assimilative force, families nevertheless are frequently unprepared for the eventuality of their children's native language erosion as they focus on learning the target language. This underestimation of the negative force the $\mathrm{L} 2$ can have on the native/heritage language is an often-noted problem (Wong Fillmore, 1991; King, Fogle, \& LoganTerry, 2008; Schwartz, 2013). It is a steep price to pay for their children's accelerated growth in the new language.

\section{Conclusion}

In order to sustain multilingualism in any society, the family must be complicit in, if not the central focus of much of multi-language development, fostering children's attitudes and stances as well as their funds of linguistic and cultural knowledge. By focusing on the family as the site of heritage language or L2 or L3 language learning and development, we can better understand the processes by which a family can both resist $L 1$ erosion and promote bilingualism. In this process, it is vital to take into account the voices of both the parents and their children in order to gain a more nuanced, valid picture of what factors go into language maintenance while attempting to develop additive bilingualism.

The group of academic educator parents selected for this study was assumed to be singularly equipped for the challenge - all were in the language education field and showed themselves to be well-informed regarding L1 erosion and capable of using their agency to hinder that loss and to create a space in which the L1 could be nurtured. All the parents had expressed the major goal of 
enabling their children to learn English as proficiently as possible, while aiming to achieve bilingual capability in their children. Yet it was striking to note how little deliberate thinking had gone into the preservation of the L1. The general belief (expressed and implied) which underlies a possible cavalier attitude toward the native language is that it is hard-wired and its loss seems somehow inconceivable.

As interviews were conducted, it soon became clear that the ultimate question to be investigated with this or any group wishing to achieve bilingualism between the native language and the $L 2$ was a simple one: Does the very absence of specific, mutually agreed-upon plans and strategies for the native L1's maintenance and development in the home endanger its continued survival? Does it predispose it to erosion and eventual loss?

\section{References}

Aronson, J. (1994). A pragmatic view of thematic analysis. The Qualitative Report, 2(1), 1-3.

Baker, C. (2011). Foundations of bilingual education and bilingualism ( ${ }^{\text {th }}$ ed.). Clevedon, UK: Multilingual Matters.

Collier, V. P. (1989). How long? A synthesis of research on academic achievement in second language. TESOL Quarterly, 23(3), 509-531.

De Houwer, A. (1990). The acquisition of two languages: A case study. Cambridge, UK: Cambridge University Press.

Döpke, S. (1992). One parent one language: an interactional approach. Amsterdam, The Netherlands/Philadelphia, PA: John Benjamins.

Fishman, J. A. (2000). Reversing language shift: RLS theory and practice revisited. In G. Kindell \& M. P. Lewis (Eds.), Assessing ethonolinguistic vitality: Theory and practice (pp. 1-25). Dallas, TX: SIL International.

Garcia, M. (2003). Recent research on language maintenance. Annual Review of Applied Linguistics, 23, 22-43. 
Guardado, M. (2002). Loss and maintenance of first language skills: Case studies of Hispanic families in Vancouver. Canadian Modern Language Review, 5(3), 341-363.

Gumperz, J. J., \& Cook-Gumperz, J. (1982). Language and social identity. Cambridge, UK: Cambridge University Press.

King, K. A., Fogle, L., \& Logan-Terry, A. (2008). Family language planning. Language and Linguistics Compass, 2(5), 907-922.

Kouritzin, S. G. (2000). A mother's tongue. TESOL Quarterly, 34(2), 311-324.

McKay, S. L., \& Wong, S. C. (1996). Multiple discourses, multiple identities:

Investment and agency in second-language learning among Chinese adolescent immigrant students. Harvard Educational Review, 66(3), 577608.

Norton Peirce, B. (1995). Social identity, investment, and language learning. TESOL Quarterly, 29 (1), 9-31.

Schecter, S. R., \& Bayley, R. (1997). Language socialization practices and cultural identity: Case studies of Mexican-descent families in California and Texas. TESOL Quarterly, 31(3), 513-541.

Schwartz, M. (2013). Immigrant parents' and teachers' views on bilingual preschool language policy. Language and Education, 27(1), 22-43.

Tajfel, H. (1974). Social identity and intergroup behaviour. Social Science Information, 13(2), 65-93.

Wong Fillmore, L. (1991). When learning a second language means losing the first. Early Childhood Research Quarterly, 6, 323-346.

\section{Martha Nyikos}

Indianos universitetas, Blumingtonas, Jungtinès Amerikos Valstijos; nyikos@indiana.edu

\section{DVIKALBYSTE் IR ŠEIMA: TĖVU İSITIKINIMAI, VAIKU SAVARANKIŠKUMAS}

Santrauka. Globalizacija daro itaką šeimu judejimui iš ju gimtosios (pirmosios) kalbos aplinkos i aplinka, kurioje ju paveldetoji (pirmoji) kalba yra mažumos kalba. Šio tyrimo objektas - laikinai (1-7 m.) Jungtinèse Amerikos Valstijose gyvenančios šeimos ir ju 
mokyklinio amžiaus vaikai. Nagrinejjama, kaip tokios šeimos išlaiko savo gimtaja kalba; kaip galima išlaikyti gimtaja kalba, susiduriant su socialiniais, emociniais, lingvistiniais ir asmeniniais iššūkiais; ar nepakankamai ivertinta paveldètosios kalbos erozija lemia sieki išlaikyti vaiko gimtaja kalbą naujame socialiniame ir mokykliniame kalbos dominantès kontekste. Tai tik keletas klausimu būsimos studijos, kurios tris pavyzdžius (tèvu ir vaiku poros) pristatome šiame darbe. Tyrimo išvada - tèvu isitikinimai dèl gebèjimo atkurti kalba, atsižvelgiant i didejjančią vaiku sociolingvistinę kompetencija ir savarankiškuma antrosios kalbos aplinkoje, daro poveiki vaiku pirmosios kalbai išlaikymui, o tai gali sukelti sunkumu ne tik vaikams, ju tèvams, bet ir tèvu ir vaiku tarpusavio santykiams.

Pagrindinès sąvokos: šeimos kalbos išlaikymas, paveldetoji kalba, kalbos strategijos, mažumos kalba, gimtosios kalbos išlaikymas, dvikalbè kalbos erozija. 